\title{
ПОРУШЕННЯ ІМУННОГО ГОМЕОСТАЗУ В РАННІЙ ПЕРІОД РОЗВИТКУ ВИРАЗКОВОЇ ХВОРОБИ ШЛУНКА НА ТЛІ ЕКСПЕРИМЕНТАЛЬНОЇ ПНЕВМОНIÏ
}

Вступ. У даній статmі наведено результати визначення показників імунного гомеостазу за умови розвитку поєднаної патології (експериментальної пневмонії і виразкової хвороби шлунка). Імунну систему характеризували за кількістю Т-лімфоцитів, оскільки вони є основою клітинної ланки специфрічної імунної відповіді, та концентрацією В-лімфоцитів і циркулюючих імунних комплексів, які відповідають за гуморальну ланку імунітету.

Мета дослідження - за вмістом T-, В-лімфроцитів, циркулюючих імунних комплексів оцінити імунну систему при розвитку експериментальної пневмонії і виразкової хвороби шлунка.

Методи дослідження. Експериментальне дослідження проводили на 39 морських свинках-самцях. Експериментальну пневмонію викликали за методом В. Н. Шляпникова та ін., виразкову хворобу шлунка моделювали за методом В. І. Комарова. Визначали вміст Т- і В-лімсроцитів (СДз та СД19) у крові за методом Є. Ф. Чернушенко, Л. С. Когосової, рівень циркулюючих імунних комплексів у крові - за методом V. Haskova, J. Kaslik.

Результати й обговорення. Як свідчать результати експериментального дослідження, ранній період розвитку (на 4-ту і 8-му доби) виразкової хвороби шлунка та пневмонії характеризувався такими змінами імунного гомеостазу: зниженням рівня Т-лімфроцитів і збільшенням вмісту В-лімфоцитів та циркулюючих імунних комплексів у крові морських свинок.

Висновок. Виявлено депресію клітинного і зростання гуморального виду імунітету за умов розитку експериментальної пневмонії і виразкової хвороби шлунка.

КЛЮЧОВІ СЛОВА: Т-лімфоцити; В-лімфоцити; циркулюючі імунні комплекси; виразкова хвороба шлунка; експериментальна пневмонія.

ВСТУП. Відповідно до Міжнародної класифрікації хвороб, травм і причин смерті 10-го перегляду (International Statistical Classification of Diseases, Tenth Revision, 1992), пневмонії - це група різних за етіологією, патогенезом і морфологічною характеристикою гострих вогнищевих інфекційно-запальних захворювань легень із переважним втягненням у патологічний процес респіраторних відділів з обов'язковою наявністю внутрішньоальвеолярної запальної ексудації [1]. Розвиток, перебіг і закінчення запалення (пневмонії) залежать як від вірулентності збудника, так і від рівня імунної відповіді макроорганізму на генетично чужорідний агент [1].

3 літератури відомо, що у хворих на пневмонію порушується імунний статус [1]. У даній роботі визначали показники імунного гомеостазу за умови розвитку поєднаної патології (експериментальної пневмонії (ЕП) і виразкової хвороби шлунка (ВХШ)). Імунну систему характерис) Л. О. Фурдичко, 2017. зували за кількістю Т-лімфроцитів, оскільки вони $€$ основою клітинної ланки специсрічної імунної відповіді, та концентрацією В-лімфоцитів і циркулюючих імунних комплексів (ЦІК), які відповідають за гуморальну ланку імунітету. Одним із найбільш важливих показників імунітету в патогенезі тяжких фрорм інфекційних захворювань $€$ надмірне збільшення кількості ЦІК у сироватці крові. Утворення ЦІК є оразою нормальної імунної відповіді на антигени, підвищення ЦІК відмічають при тяжких дисрузних процесах [2].

Мета дослідження - за вмістом Т-, В-лімфоцитів, циркулюючих імунних комплексів оцінити імунну систему при розвитку експериментальної пневмонії і виразкової хвороби шлунка.

МЕТОДИ ДОСЛІДЖЕННЯ. Експериментальне дослідження проводили на 39 морських свинках-самцях масою 180-210 г. Піддослідних тварин поділили на три групи: 1-ша група - контроль (15 інтактних тварин); 2-га - морські свин- 
ки 3 ЕП+ВХШ на 4-ту добу (12 тварин); 3-тя морські свинки з ЕП+ВХШ на 8-му добу (12 тварин).

Експериментальну пневмонію викликали за методом В. Н. Шляпникова та ін. [3], виразкову хворобу шлунка моделювали за методом В. І. Комарова [4]. Визначали вміст Т- і В-лімфоцитів (СД3 та СД19) у крові за методом Є. Ф. Чернушенко, Л. С. Когосової [5], рівень ЦІК у крові - за методом V. Haskova, J. Kaslik [6].

Отримані цифрові результати досліджень опрацювали статистичним методом за Стьюдентом.

Для інтерпретації одержаних даних умовно виділили два періоди: ранній - морські свинки на 4-ту і 8-му доби розвитку ЕП+ВХШ, пізній тварини з ЕП+ВХШ на 14-ту і 18-ту доби експерименту.

Евтаназію тварин здійснювали під ефірним наркозом на 4-ту та 8-му доби фрормування запального процесу в легенях і виразкової хвороби шлунка.

РЕЗУЛЬТАТИЙ ОБГОВОРЕННЯ. ЯК свіДчаТЬ результати експериментального дослідження, ранній період розвитку ЕП+ВХШ характеризу- вався змінами показників імунного статусу відносно контролю.

Так, на 4-ту добу формування ЕП і ВХШ спостерігали зниження рівня Т-лімфоцитів на $19,8$ \% ( $\mathrm{p} \leq 0,05)$, а на 8-му добу цього експерименту мало місце значне його зменшення на

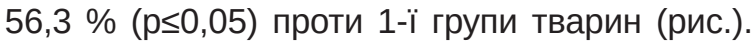
Таким чином, можна стверджувати, що ранній період розвитку поєднаної патології супроводжувався депресією клітинного імунітету.

Гуморальний імунітет оцінено при ЕП+ВХШ за визначенням вмісту В-лімфоцитів та ЦІК у крові.

Концентрація В-лімфроцитів на 4-ту добу підвищилась на 36,7 \% ( $\leq \leq 0,05)$ відносно інтактних тварин. Пізніше (на 8-му добу цих експериментальних моделей хвороб) їх рівень зазнав більш вираженого зростання - на 68,5 \% $(p \leq 0,05)$ проти групи контролю (рис.).

Важливим маркером імунокомплексного пошкодження клітин $є$ дослідження циркулюючих імунних комплексів у крові при виразковій хворобі шлунка на тлі пневмонії. Виявлено, що ранній період розвитку даних моделей хвороб характеризувався підвищенням ЦІК на 39,4 \% $(\mathrm{p} \leq 0,05)$ та $68,8 \%(\mathrm{p} \leq 0,05)$ відповідно на 4-ту і 8-му доби експерименту (рис.).

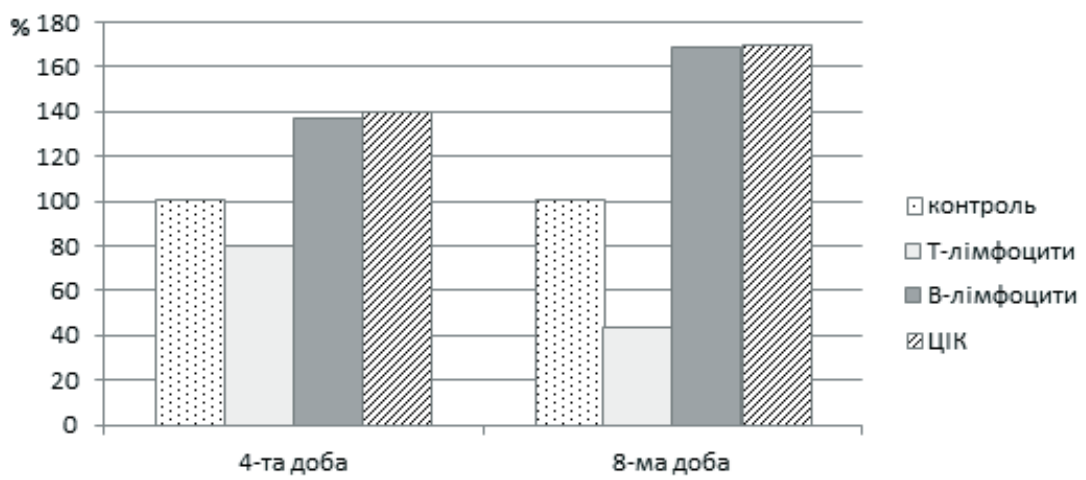

Рис. Вміст окремих показників клітинного і гуморального імунітету в крові у ранній період фрормування ЕП+ВХШ (у \% від контролю).

ВИСНОВОК. Дослідження окремих показників імунної системи показало порушення їх фрункціонування за умов фрормування виразкової хвороби шлунка на тлі пневмонії в морських свинок, що проявлялося стимуляцією гуморального на тлі депресії клітинного імунітету.

\section{СПИСОК ЛІТЕРАТУРИ}

1. Мікробіологічні та імунологічні аспекти негоспітальної пневмонії / І. Й. Сидорчук, Н.М.Каспрук, Л. І. Сидорчук, Р. І. Сидорчук // Міжнар. ендокрин. журн. - 2013. - № 6 (54). - С. 179-181.

2. Можаєв $€$. О. Виразність імунотоксикозу у дітей на гостру деструктивну пневмонію / Є. О. Можаєв // Укр. мед. альм. - 2010. - 13, № 4. - С. 135-136.
3. Экспериментальные модели острых пневмоний, вызванных условно-патологическими бактериями и их ассоциацией : метод. указания / сост. : В. Н. Шляпников, Т. Л. Солодова, С. А. Степанов. Саратов, 1998. - 30 с.

4. Скляров О. Я. Моделирование процессов гастропротекции и ульцерогенеза в слизистой оболоч- 
ке желудка / О. Я. Скляров, Е. Я. Скляров // Пробл. патологии в эксперименте и клинике. - 1991. - XIII. C. $72-73$.

5. Чернушенко Е. Ф. Иммунология и иммунопатология заболеваний легких / Е. Ф. Чернушенко, Л. С. Когосова. - К. : Здоров'я, 1981. - 208 с.
6. Haskova V. Novy zpusob stanoveni circulujicich imunokomplexy w lidskych serech / V. Haskova, J. Kaslik, M. Matejckava // Cas. Lek. Ces. - 1977. - 116, № 14. S. 436-437.

\section{REFERENCES}

1. Sydorchuk, I.Y., Kaspruk, N.M., \& Sydorchuk, L.I. (2013). Mikrobiolohichni ta imunolohichni aspekty nehospitalnoi pnevmonii [Microbiological and immunological aspects of community-acquired pneumonia]. Mizhnar. endokryn. zhurn. - International Journal of Endocrinology, 6 (54), 179-181 [in Ukrainian].

2. Mozhaiev, Ye.O. (2010). Vyraznist imunotoksykozu u ditei na hostru destruktyvnu pnevmoniiu [Expressiveness of monotonicity in children with acute destructive pneumonia]. Ukr. med. alm. - Ukrainian Medical Almanac, 13 (4), 135-136.

3. Shlyapnikov, V.N., Solodova, T.L., \& Stepanov S.A. (1998). Eksperymentalnye modeli ostrykh pnevmoniy, vyzvannykh uslovno-patologicheskimi bakteriyami i ikh assotsyatsyey: metod. Ukazaniya [Experimental models of acute pneumonia caused by opportunistic bacteria and pathological association: method. instructions]. Saratov [in Russian].

4. Sklyarov, O.Ya., \& Sklyarov, E.Ya. (1991). Modelirovaniye protsessov gastroprotektsyi i ultserogenesa v slizistoy obolochke zheludka [Modeling of processes of gastroprotection and ultserogenesis in mucous membrane]. Probl. patologii v eksperymente i klinike Problems in Pathology and Clinical Experiment, XIII, 72-73.

5. Chernushenko, E.F., \& Kohosova L.S. (1981). Immunologiya i immunopatologiya zabolevaniy legkikh [Immunology and immunopathology of lung diseases]. Kyiv: Zdorovia [in Russian].

6. Haskova V., Kaslik J., \& Matejckava M. (1977). Novy zpusob stanoveni circulujicich imunokomplexy lidskych serech. Cas. Lek. Ces., 116 (14), 436-437.

\section{НАРУШЕНИЕ ИММУННОГО ГОМЕОСТАЗА В РАННИЙ ПЕРИОД РАЗВИТИЯ ЯЗВЕННОЙ БОЛЕЗНИ ЖЕЛУДКА НА ФОНЕ ЭКСПЕРИМЕНТАЛЬНОЙ ПНЕВМОНИИ}

\section{Резюме}

Вступление. В данной статье приведены результаты определения показателей иммунного гомеостаза при развитии сочетанной патологии (экспериментальной пневмонии и язвенной болезни желудка). Иммунную систему характеризовали по количеству Т-лимфоцитов, поскольку они являются основой клеточного звена специфрического иммунного ответа, и концентрации В-лимороцитов и циркулирующих иммунных комплексов, которые отвечают за гуморальное звено иммунитета.

Цель исследования - по содержанию $T$-, В-лимфроцитов, циркулирующих иммунных комплексов оценить иммунную систему при развитии экспериментальной пневмонии и язвенной болезни желудка.

Методы исследования. Экспериментальное исследование проводили на 39 морских свинках-самцах. Экспериментальную пневмонию вызывали по методу В. Н. Шляпникова и др., язвенную болезнь желудка моделировали по методу В. И. Комарова. Определяли содержание Т- и В-лимороцитов (СДЗ и СД19) в крови по методу Е. Ф. Чернушенко, Л. С. Когосовой, уровень циркулирующих иммунных комплексов в крови - по методу V. Haskova, J. Kaslik.

Результаты и обсуждение. Как свидетельствуют результаты экспериментального исследования, ранний период развития (на 4-е и 8-е сутки) язвенной болезни желудка и пневмонии характеризовался 
такими изменениями иммунного гомеостаза: снижением уровня Т-лимфоцитов и увеличением содержания В-лимфоцитов и циркулирующих иммунных комплексов в крови морских свинок.

Вывод. Выявлено депрессию клеточного и рост гуморального вида иммунитета в условиях развития экспериментальной пневмонии и язвенной болезни желудка.

КЛЮЧЕВЫЕ СЛОВА: Т-лимфоциты; В-лимфоциты; циркулирующие иммунные комплексы; язвенная болезнь желудка; экспериментальная пневмония.

L. O. Furdychko

DANYLO HALYTSKYI LVIV NATIONAL MEDICAL UNIVERSITY

\section{COMPROMISED IMMUNE HOMEOSTASIS IN THE EARLY PERIOD OF GASTRIC ULCER AGAINST THE BACKGROUND OF EXPERIMENTAL PNEUMONIA}

Summary
Introduction. The article adduces the obtained results of the indices of immune homeostasis in the development of combined pathology (experimental pneumonia (EP) and gastric ulcer (GU) of the stomach). The immune system is characterized by the number of T-lymphocytes since they are the basis of the cellular component of the immune response and the concentration of B-lymphocytes and circulating immune complexes (CIC), which are responsible for cellular immunity.

The aim of the study - the content of T-lymphocytes, CEC to assess the immune system in the development of EP and GU.

Materials and Methods. This experimental study was conducted on 39 guinea pigs-males. Experimental pneumonia caused by the method of V. N. Shliapnikova, T. L. Solodova [et al.] Gastric ulcer of the stomach was simulated by the method of V. I. Komarova. We determined the content of T- and B-lymphocytes (SD3 and SD19) in the blood by the method of E. F. Chernushenko, L. S. Kohosova. The level of circulating immune complexes (CIC) in the blood by the method of Haskova V., Kaslik J..

Results and Discussion. The results of experimental studies established that early period of development (4th and $8^{\text {th }}$ day) of gastric ulcer and pneumonia is characterized by the following changes of immune homeostasis: decrease in the level of T-lymphocytes and elevated levels of lymphocytes and circulating immune complexes in the blood of Guinea pigs.

Conclusion. A depression of cell growth and humoral types of immunity in terms of experimental pneumonia and gastric ulcer was revealed.

KEY WORDS: T-cells; B-cells; CIC; gastric ulcer; experimental pneumonia. 